\title{
SOBRE A DATAÇÃO DE VOCÊ, OCÊ E SENHORITA
}

\author{
ON THE DATING OF VOCÊ, OCÊ AND SENHORITA
}

\author{
Odete Pereira da Silva MENON \\ Universidade Federal do Paraná -CNPQ ${ }^{1}$
}

\begin{abstract}
Resumo
Conhecer a data em que uma palavra figurou, pela primeira vez, na língua não serve só para efeitos de datação. Essa informação é importante, pois pode balizar os estudos sobre as etapas implementação e avaliação (WEINREICH, LABOV; HERZOG, 1968) das mudanças linguísticas. Assim, o presente estudo é uma tentativa de situar, histórica e socialmente, o comportamento das formas de se dirigir ao interlocutor, usando as variantes mais gramaticalizadas do pronome vossa mercê, primeiro em Portugal (você), depois no Brasil (você/ocê/cê), corrigindo, atualizando e fixando datas de aparecimento dessas ocorrências. Com a utilização de obras de autores nascidos entre o século XVII e o início do XX foi possível, inclusive, adiantar em meio século a datação do substantivo senhorita, indicador, talvez, de um novo estatuto para a mulher.
\end{abstract}

Palavras-chave: Implementação/avaliação.Você/ocê/cê. Datação de senhorita.

\begin{abstract}
Knowing the date when a word first appeared in the language is not only helpful for linguistic dating purposes. This information is important because it can guide studies about the actuation problem and evaluation stages (WEINREICH; LABOV; HERZOG, 1968) of linguistic changes. The present study is an attempt to locate, historically and socially, the behavior of forms to address the interlocutor, using more grammaticalized variants of the pronoun (honorific form) vossa mercê, first in Portugal (você - you, en English) then in Brazil (você and ocê/cê - contracted forms of você ), correcting, updating and fixing the appearance dates of these occurrences. By referring to literature authors born between the 17th Century and the beginning of the 20th Century it was also possible to anticipate by half a century the dating of the noun senhorita (Eng. mistress), maybe an indicator of a new statute for women.
\end{abstract}

Keywords: Implementation/evaluation. Você/ocê/cê. Dating of senhorita.

\section{INTRODUÇÃO}

Estabelecer a data da primeira ocorrência de uma dada forma na língua portuguesa (tanto no português europeu, doravante PE, como no português do Brasil, doravante PB) é tarefa que ainda está praticamente por fazer, apesar de alguns dicionários parciais desenvolvidos em diferentes épocas por distintos autores, alguns se limitando à data de entrada no PE, outros incluindo também algumas lexias do PB. Boa parte deles foi aproveitada por Antônio Houaiss quando da elaboração do seu dicionário (HOUAISS,

\footnotetext{
${ }^{1}$ Processo 308356/2006-3, PQ II
} 
2001). Atualmente existem alguns trabalhos em curso, de feitura de dicionários do português arcaico, como o liderado por Américo Venâncio Machado Filho, da UFBA.

Como existe uma quantidade enorme de documentos antigos guardados em arquivos (públicos e particulares, do Brasil e de Portugal) ainda não suficientemente explorados, apesar dos esforços de vários pesquisadores, a questão da datação está sempre sujeita a atualizações. É sempre possível, e desejável, que alguém descubra um documento mais antigo que contenha determinadas formas, a fim de podermos situar, no tempo, quando um vocábulo adquiriu foros de escrita; por isso, sempre que se aborda esse assunto, deve se ter o máximo cuidado em não maximizar os achados: eles sempre estarão sujeitos a contestação.

Portanto, é com esse espírito que participo a sinalização de duas datas: uma delas, para fazer uma pequena correção à data e ao documento veiculados pelo dicionário Houaiss, com relação ao pronome você; a outra para recuar aquela referente ao substantivo senhorita, mencionada pelo mesmo dicionário. Além disso, trazer, talvez, a documentação da primeira ocorrência escrita da etapa seguinte do processo de gramaticalização do você: o ocê (grafado ussê).

\section{DATAÇÃO DE VOCÊ}

Saber quando a forma de se dirigir ao interlocutor, oriunda da locução ou sintagma nominal (LN ou SN) a vossa mercê (presente nos textos desde o século XIII, cf. MENON, 2006), que se gramaticalizou, inicialmente, como o pronome vossa mercê, (perdendo a possibilidade de se construir com o artigo) começa a aparecer na forma contracta você é importante: primeiro, para se determinar quando ela se tornou, realmente, no $\mathrm{PE}$, um pronome de segunda pessoa, no trato de igual para igual ou de superior para inferior, invertendo a significação histórica da forma honorífica ${ }^{2}$, que era usada de inferior para superior. A respeito dessa inversão, a partir de Cintra (1972, p. 33), podemos inferir que, desde pelo menos a segunda metade do século XVII, o pronome você já seria marcado, no sentido sociolinguístico, como forma de se dirigir a inferior, visto já estar presente essa acepção no Vocabulário de Bluteau, publicado em 1721:

\footnotetext{
${ }^{2}$ Forma honorífica é uma expressão usada para designar as formas de se dirigir ao interlocutor, constituídas do pronome vossa mais um substantivo (majestade, alteza, excelência, senhoria, santidade, eminência, paternidade, magnificência, relativas aos postos ou "honras" ocupados pelas pessoas), por processo de gramaticalização das LNs. correspondentes, perdendo todas o artigo definido e a capacidade de desencadear a concordância nominal (CN) com o substantivo que as originou (cf. "Vossa Senhoria está servido?” e não servida, como quando era substantivo. É sob esse aspecto estrutural, morfossintático, que se pode argumentar que as formas honoríficas constituem verdadeiros pronomes, pois como eles se comportam. Uma das características do pronome pessoal, na função de sujeito, é desencadear a concordância do predicativo, que vai ser feita de acordo com o sexo do locutor ou interlocutor, conforme o caso. Se um ministro de Estado for mulher - o que hoje não é raro no Brasil—, e um repórter perguntar se ela (a atual ministra da Casa Civil) vai se apresentar à próxima eleição para Presidente da República, indagará: “V. Ex. ${ }^{a}$ é pré-candidata?”. Dá-se, pois, a CN da mesma forma como o locutor utiliza o pronome $e u$ : se for um homem quem fala, o predicativo vai para o masculino; se for mulher, para o feminino: "Eu estou cansado/a."). É o que as gramáticas tradicionais (GTs.) chamam de formas de tratamento. No entanto, essa distinção feita pelas GTs. é indevida, pois os pronomes pessoais de segunda pessoa tu, você, o senhor (e formas plurais) são igualmente formas de tratamento, porque são empregadas para nos dirigirmos ao alocutário, isto é, a pessoa com quem falamos.
} 
Poder-se-iam multiplicar os exemplos comprovativos da decadência de Vossa Mercê, que condiciona naturalmente a expansão progressiva e bastante rápida de Vossa Senhoria e V. Excelência como formas associadas à cortesia, ao respeito, à "reverência".

Sem deixar de apontar que você já se encontra, embora esporàdicamente, em textos do século XVIII (e até da primeira metade deste século), como tratamento de emprego possível de igual para igual, entre amigos, mesmo da alta burguesia, sem que pareça, portanto, associar-se-lhe qualquer matiz despectivo, apesar da observação que se recolhe em Bluteau em 1721 ("trato usado com gente inferior"). (Ver por exemplo nas Guerras do Alecrim e da Manjerona, de António José da Silva: "Se chego a vencer / de Nise o rigor / de gosto morrer / você me verá”)

Segundo, para verificarmos desde quando existe no PB, no trato de igual para igual, ou de superior para inferior ou, até, como hoje, de inferior para superior, quando autorizado: p. ex., a partir da segunda metade do século $\mathrm{XX}$, em alguns casos e em algumas classes sociais, os pais começaram a admitir o uso de você (ou tu, naqueles dialetos em que esse é o pronome íntimo) por parte dos filhos, em substituição ao respeitoso o(a) senhor(a).

Antenor Nascentes já registra, em 1949-50 (2003, p. 426), o tratamento você dos filhos para os "pais modernos" que "rejeitam a Senhoria”, ao lado de papai/mamãe e senhor/senhora (os últimos usados, segundo ele, "quando há certa austeridade”). Diz, ainda, que "Os avós são tratados de vovô, vovó, senhor, senhora. [...] A Senhoria aqui explica-se pela idade, mas assim mesmo há avós que gostam de ser tratados por você: os avós modernos.”

\subsection{Em Portugal}

As referências mais antigas do pronome, nessa forma, costumam ser atribuídas ao polígrafo D. Francisco Manuel de Mello (1608-1666 ${ }^{3}$; doravante DFMM). No verbete você, o dicionário Houaiss consigna a data de 1865 para a primeira abonação do pronome, na farsa Fidalgo Aprendiz, inserida na edição princeps da Obra Poética do autor, publicada naquela data em Lyon, França, em três volumes, porém há aí um equívoco: no Fidalgo, só aparece a forma Voffancé (I, verso 934; ver exemplo (05), abaixo), além de Voffa mercé (I, 64; II, 88; III, 303) e Voffa Senhoria (I, 155 e 299). Oliveira (1943, p. 06) fixa a data provável da composição da farsa (1646), o local (Torre de Belém, uma das duas prisões em que esteve confinado DFMM, aguardando a sua sentença de degredo para o Brasil) e a finalidade da obra - ser representada na Corte, como parece que foi:

\footnotetext{
${ }^{3}$ As datas entre parênteses se referem, respectivamente, às datas de nascimento e morte do autor, conforme constam das fichas catalográficas da BNL (Biblioteca Nacional de Lisboa).

${ }^{4}$ A citação — jornada (I, II e III), verso — se faz pela edição de Oliveira (MELO, 1943). Na edição princeps, a farsa aparece a partir da página 238 do II tomo (cf. microfilme F 6578, da Biblioteca Nacional de Lisboa).
} 
[O Fidalgo Aprendiz] foi escrito na Torre de Belém e já estava concluído em 03 de fevereiro de 1646. Destinava-se aos Reis, como indica a rubrica da edição príncipe - Farça que se presente a suas Altezas, e foi-lhes realmente apresentado por um parente de D. Francisco Manuel com a aceitação do Paço, provàvelmente D. Francisco de Melo.

Sobre a questão de DFMM, falar e escrever igualmente em português e castelhano e, por isso, poder ter havido alguma "contaminação" nos seus escritos portugueses, o mesmo editor declara, no tocante ao português da farsa:

[...] a linguagem do Fidalgo Aprendiz, intencionalmente popular e arcaizante, é um modelo de bom português velho relho ${ }^{5}$ aprendido na lição de Sá de Miranda, de Jorge Ferreira de Vasconcelos e de Camões. O autor pretendeu mesmo acentuar o seu portuguesismo estreme e o seu desprezo pelos castelhanos. São numerosas as formas populares, como alembrar [...] vossancê, etc. (OLIVEIRA, 1943, p. 30)

Note-se como Oliveira caracteriza a língua empregada por DFMM: popular e arcaizante. Sob tal perspectiva, a forma contracta vossancê seria já termo antigo na época do autor, usado na boca de um mestre de esgrima, que vem dar lições ao aprendiz de fidalgo. Cintra (1972, p. 30) justificava essa possibilidade, ao tratar das mudanças na sociedade portuguesa e, consequentemente, nas novas formas que a nobreza, velha ou nova, queria receber como tratamento, quando afirma (negritos acrescentados):

Preocupação de muitos, antes de mais nada, em não serem tratados por Vossa Mercê e muito menos por uma das formas fonéticas decadentes vossancê ou você (esta última, salvo êrro, atestada até agora pela primeira vez pouco antes de 1666) ${ }^{(*)}$, formas abreviadas ìntimamente associadas à degradação semântica da já antiga forma de cortesia.

${ }^{(*)}$ Exemplo colhido na Feira de Anexins de Dom Francisco Manuel de Melo (p. 196 da ed. de 1916) por José Pedro Machado (Dicionário Etimológico da Língua Portuguesa, II, p. 2180b). A forma espanhola usted está documentada em $1620^{6}$ (vusted em 1619, vuasted em 1617, vuested em 1635) segundo o Breve Diccionario Etimologico de la Lengua Castellana, por J. Corominas, Madrid, 1961, p. 595.

Constatamos, a partir dessa citação de Cintra, caber ao dicionarista José Pedro Machado o mérito de haver localizado o que se considerava ser a primeira atestação, por escrito, da ocorrência do pronome na forma contracta.

O exemplo, no entanto, não é único, na obra: você vai aparecer consistentemente na Feira de Anexins ${ }^{7}$ (ver MENON, 2006) que, por infelicidade, permaneceu manuscrita até 1875, quando foi publicada em edição organizada por Innocêncio Francisco da

\footnotetext{
${ }^{5}$ Conforme os versos 312-313 da farsa: "Falarei, como mandais, / bom portugues velho relho".

${ }^{6}$ Veja-se, mais adiante, a informação do uso de usted por DFMM.

${ }^{7}$ No dicionário Houaiss, a Feira, utilizada para outras abonações, aparece como de 1666: como não se sabe exatamente quando foi escrita, parece que essa data foi adotada por ser a da morte do autor.
} 
Silva $^{8}$ (nela, o pronome aparece grafado Voffé). Como se trata de uma obra rara, parece se justificar sua não-menção por alguns autores que já se dedicaram ao estudo da trajetória do pronome você no português. Serra (1998, p. IX), organizador de uma recente edição dos Apólogos Dialogais, afirma que a Feira deveria ser apenas "o esboço" do que poderia ter constituído o quinto apólogo de DFMM. Como o você não aparece nos quatro apólogos (somente a forma vossa mercê), seria de se perguntar se, no caso de o texto da Feira ser "passado a limpo" para publicação", a forma teria sido alterada pelo próprio autor ou se ela se manteria. O interessante a notar, também, é que na edição das Cartas Familiares, feita pelo próprio autor ${ }^{10}$, não aparece nenhuma ocorrência de você: somente vossa mercê (abreviado, no mais das vezes, em V. M., na edição de Sarmento, 1981); o tratamento íntimo tu não aparece ${ }^{11}$, nem nas missivas a amigos, nem aos parentes - a esses trata em geral por vós, V. M. ${ }^{12}$ ou V. S., conforme o caso. No total são 581 missivas, assim distribuídas por tratamento: vós ${ }^{13}$ (89 cartas em português e 03 em espanhol), vós + V. M. na mesma carta (17 cartas); V. M. (309 cartas em português e 09 em espanhol); V. P. ${ }^{14}$ (30 cartas, mais 03 com V. Rev. ${ }^{\text {ma }}$, 02 com V. Santidade, 01 com V. Em. ${ }^{\text {a }}$ ); V. S. (91 cartas em português e 06 em espanhol); V. Ex. ${ }^{\text {a }}$ (06 cartas em português e 02 em espanhol); V. Majestade (03 cartas); V.A. (03 cartas em espanhol), para destinatários cuja hierarquia ou papel na sociedade assim o exigissem (as demais cartas aparecem sem forma de tratamento).

Porém, se não sabemos quando foi escrita a Feira, podemos ao menos assinalar uma data, 1665, em que, ainda em vida de DFMM, foram publicadas as suas Obras Métricas

\footnotetext{
${ }^{8}$ A obra teria uma nova edição em 1916, aquela indicada por José Pedro Machado, idêntica à primeira, salvo no que toca a algumas coisas da introdução do organizador.

${ }^{9}$ Veja-se o que diz Sarmento (1981: 41) a respeito da "limpeza” a que o autor se refere na carta 295:

“Como é óbvio, D. Francisco Manuel preparou as cartas para a publicação. As alterações introduzidas são ligeiras, como se pode verificar pelo cotejo das cartas de que possuímos duas versões. Reduzem-se à supressão de certas referências pessoais (o que, diga-se de passagem, torna por vezes a interpretação mais difícil) e a pequenas modificações sem importância.”

${ }^{10}$ Nas duas reproduções fac-similadas, cartas autógrafas 441 e 580 (SARMENTO, 1981, p. 553-4; códice 51-III-58, da Biblioteca da Ajuda, fl. 539 e 201, respectivamente), ocorre a forma abreviada VM. As Cartas foram editadas pela primeira vez "em Roma, no ano de 1664, quando o autor ali se encontrava em serviço diplomático.” (SARMENTO, 1981, p.13). Sobre o papel das abreviaturas no processo de implementação do você, consulte-se Chaves (2006).

${ }^{11} \mathrm{O}$ tu só aparece numa carta (n. ${ }^{\circ}$ 535) em uma das suas obras, dirigindo-se ao leitor e na 562, uma carta em espanhol.

${ }^{12}$ Os usos de vossa mercê parecem ser mais formais, guardando um sentido mais próximo do uso do honorífico: são cartas dirigidas tanto a ministros, como a amigos e parentes. Também vós aparece empregado tanto para destinatário singular como quando são vários.

${ }^{13}$ É bastante interessante a seguinte reflexão de D. Francisco M. Melo sobre o modo como tratar a um estranho: “Com propriedade chamamos peregrino ao que é raro, e também ao estranho, porque na nossa admiração vem a igualar-se o que vimos poucas vezes como o que nunca. Vós, Senhor, assi sois peregrino para mi; e não menos porque vos ignoro que porque vos admiro. Olhai! Eu uso deste modo de tratamento, porque, buscando um que venha ao justo a vossa muita cortesia, não acho outro que mais lhe convenha que este donde se contém os maiores acatamentos. Converte-o lá no que vos toca que, se aos senhores se deve maior vantagem, vós sois senhor sem falta, ao menos senhor no que dizeis, que o por donde eu o digo. Tomai o que vos tocar, que, se é o que interiormente desejo, não vos dará pelo artelho a senhoria nem a excelência. Certificai-vos assi que me não sois acreedor da honra com que me tratais, que eu, por muito sobeja, não fiz ora muito em vos tornar a maior parte.” (carta 42, p. 9293, cuja ementa é "Respondendo a um papel incerto, que, com o nome de N. Calado, pedia se lhe visse e emendasse ũa obra poética que com ele se remetia”; negritos acrescentados).

14 Vossa Paternidade, para prelados, sacerdotes; para bispos e arcebispos, usava V. S. - Vossa Senhoria.
} 
(03 volumes), “en Leon de Francia, [por] Horacio Boessat y George Remeus, editores”. E, nestas, localizei várias abonações, não só de voffa ${ }^{15}$ mercé, no singular e no plural, como também da forma contracta vocé ou vocés ${ }^{16}$, além de Voffa Senhoria, com a forma reduzida ${ }^{17}$ Vô Senhoria!

Vejamos algumas das ocorrências em DFMM:

(01) Meu fenhor Dom Antonio, [...] / Huy, senhor! ifto quer voffa mercè? / Tendes dos voffos confoantes dò, / e quando deffa quinta mandeis cà, / Para que ferve hum elle, hum vos, hum tu? (Obras, p. 18: Son. XXIV, Resposta a D. Antonio Aluarez da Cunha pelo eftillo, em que lhe efcreveo outro Soneto)

(02) Voffa mercé fenhor meu, eftudante/ difto fe lhe não dâ; muito nem pouco,/ a titulo da poffe de bargante/ Vayme lendo os tercetos pouco a pouco/ defte fe troce, a aquelle faz focinho/ eu a pedir perdão, e vocé mouco. (Obras, p. 131: A Iorge da Camara, em resposta de outra)

(03) Ora tende, tende mão/ que vay o pano, e o Cabâs/ e fem razão fe lhes faz/ não dando delles razão,/ faço comemoração/ das ditas duas vazilhas,/ que fão tão honradas filhas/ que em vocé la as enchendo;/ tornarão logo, correndo/ a verme às mil maravilhas. (Obras, p. 211: Décimas XXVI, Da Ociozidade mandando hum queijo a hũa Dona.)

(04) Bem está vocés agora, / eftarão muito contentes, / cuidando que fe acabou; / efta leitura perene./ Iaz aqui nefta algibeira:/ lindo como um ramalhete,/ cuberto de hũa celada,/ de rofas, e bem me queres,/ Armados de ponto embranco,/ para que todas as vezes; / que vocés differem:/ fayão, efta Academia atropellam./ Muficos meus amados ... (Obras, p. 213-214: Romance XXVII)

(05) Guárde Deos a Voffancé. (Obras, p. 240: Fidalgo Aprendiz, farça)

Dom Francisco Manuel de Mello também satiriza o uso dos honoríficos (pronomes construídos com o possessivo Vossa, mais um substantivo indicando uma qualidade: excelência, senhoria, paternidade, majestade, alteza), como na farsa Fidalgo Aprendiz, ao construir um diálogo em que uma das personagens, ao ser tratada por voffa mercé, reclama a Senhoria (06) e a outra ironiza retrucando que não sabe quando ele terá esse direito; depois, uma outra, para dar mais cortesia, manda "Em dobro as Senhorias”(Obras, p. 245: Fidalgo Aprendiz). Vemos, em (07), a ocorrência da forma reduzida Vô Senhoria, como já tinha aparecido Voffancé, mencionada acima.

(06) A. Que manda voffa mercé? / G. Que tenhais mais cortezia/ A. Que mandais? / G. A Senhoria/ G. A Senhoria, não fey; para quando he. (Obras, p. 239)

(07) Veo cá Vô Senhoria. (Obras, p. 229: Epigrama LIII)

Como as Obras foram publicadas em vida do autor, podemos afirmar, com alguma segurança, levando-se em consideração a sua data de nascimento (1608), que você(s) já seria moeda corrente em Portugal, pelo menos em Lisboa, desde o início do século

\footnotetext{
${ }^{15} \mathrm{Na}$ forma voffa (e também em outras palavras que aparecerem em citações da época), os efes <ff $>$ devem ser interpretados como esses $<$ ss $>$ longos, característicos da grafia dos seiscentos.

${ }^{16}$ Na impressão da Feria de Anexins, a grafia utilizada é vossé.

${ }^{17}$ Provavelmente por haplologia: Vossa Senhoria $>$ Voss ${ }^{\mathbf{e}}$ Senhoria $>$ Vo Senhoria. Conforme A Tuba de Calliope, Soneto LXXXVIII: “Faça me hoje merce vo fenhoria” (MELO, 1665, tomo II: 45)
} 
XVII. E, como DFMM viveu muitos anos na Espanha ${ }^{18}$, empregou também com muita naturalidade o usted, como aparece na fala de uma personagem espanhola: "Con fu befo a ufted las manos". (Obras, p. 116). Como podemos constatar, o desenvolvimento do processo de gramaticalização do tratamento honorífico corria em paralelo em ambas as línguas.

\subsection{No Brasil}

Comumente, é atribuída ao músico Domingos Caldas Barbosa (1738-1800) a primeira ocorrência de você na pena de um brasileiro, numa das cantigas da coletânea denominada Viola de Lereno (vol. I, Lisboa, 1798, 1806; Bahia, 1813; Lisboa, 1819 e 1825; vol. II, Lisboa, 1826). Em 1955, escrevendo sobre o você, indagava Nascentes (2003, p. 438):

De quando data a palavra você no Brasil?

Por falta de estudos cronológicos, a questão é tão difícil no Brasil como em Portugal.

Em todo o caso, pode-se afirmar com segurança que já existia nos fins do século XVIII.

Lereno a emprega na cantiga Amor não é brinco:

Você trata amor em brinco.

Amor o fará chorar.

Veja lá com quem se mete,

Que não é para zombar.

Mas quem era esse Lereno, que Nascentes não identifica, porque não dá a referência da obra? A respeito dele, diz Almeida (2003, p. 77-78):

Filho de um português e de uma africana, estudou no Colégio da Companhia de Jesus do Rio de Janeiro, onde uma precoce veia poética satírica lhe veio a causar problemas, pois atingiu com os seus versos algumas personalidades, cuja influência o levou à prisão e depois ao alistamento forçado no Exército e à colocação como soldado na colónia do Sacramento, da qual apenas regressou quando, nos finais de Outubro de 1762, esse território foi ocupado pelas tropas espanholas comandadas por Pedro de Cevallos. Logrou obter saída do serviço militar e, no ano seguinte, partiu para Portugal, acabando por não poder matricular-se na Universidade de Coimbra, como era seu objectivo, devido à inesperada morte do pai. A sua afabilidade e capacidade de versejador fizeram-lhe encontrar um mecenas na pessoa de José Vasconcelos e Sousa, futuro Marquês de Belas, que o introduziu na sociedade lisboeta, tornando-se muito popular como cantor de modinhas e lundus, com o acompanhamento da viola. Pôde prosseguir os estudos, vindo a ser ordenado padre e obtendo posteriormente o lugar de capelão da Casa de Suplicação de Lisboa. A amizade do fidalgo provocou inveja em algumas figuras do círculo social e literário, tendo sido vilipendiado por

${ }^{18}$ Lembrar que Portugal esteve sob o domínio espanhol até 1640. 
Bocage e pelo padre José Agostinho de Macedo. Pertenceu à Arcádia de Roma, com o nome de Lereno Selinuntino, e foi um dos fundadores da Nova Arcádia de Lisboa, Academia fundada em 1790 com a finalidade de promover a poesia e a oratória, sucedendo à Arcádia Lusitana. A sua obra insere-se na escola arcádica, mas o rigor da forma é atenuado por elementos de espontaneidade e sentimentalismo, com a utilização de termos tropicais, transmitindo-lhe características próprias, levando a que o autor seja considerado um antecessor dos cantores populares brasileiros.

Como se pode ver pela biografia de Lereno, haveria um intervalo de quase um século entre a primeira abonação de você em Portugal (1665) e o primeiro registro por um brasileiro; no entanto descobri que, praticamente na mesma época em que Dom Francisco Manuel de Melo imprimia os volumes de sua produção poética contendo o pronome você, um brasileiro, que andou certo tempo na Corte portuguesa, também deixou consignada a forma você: trata-se do nosso Gregório de Matos (1633-1696)! Encontrei, há pouco tempo ${ }^{19}$, duas abonações de você na publicação de um códice setecentista inédito do autor (PERES; LA REGINA, 2000):

(08) 3. Lá do alto verá vossê / a puta sem intervalos/ tangida de mais badalos/ que tem a torre da Sé:/ verà andar a cabra mé/ berrando atraz dos cabroens/ os ricos pelos tostoens,/ os pobres por piedade,/ os Leigos por amizade, / os Frades pelos pismoens. (Matos, p. 133: A hum Frade, que tratava com h ua mulata chamada Vicencia)

(09) 1. Munha [sic] gente, vosse vê/ estas loucuras borrachas/ deste Capitam das tachas,/ que logo direi quem hé?/ veyo pedir de mercê./ que lhe celebrasse a cura/ de huma purgaçam madura,/ que a Amiga lhe tinha dado,/ porque sem comer mellado/ o fez cagar rapadura. (Matos, p. 144: Ao Capitam Rapadura, pedindo ao Poeta que lhe fizesse huã obra sobre havelo purgado huã Femea cõ doce de araçà).

Pelos registros de Gregório de Matos (doravante GM), podemos inferir dois fatos: (i) o pronome você era de uso no português do Brasil, já no século XVII e (ii) podia ter também pronúncia aberta na sílaba tônica (08), pois rima com Sé e mé (onomatopéia da cabra). Quanto ao estatuto social do destinatário, para se saber se era estigmatizado ou não, vemos que há dois “destinatários”: em (09) "minha gente” é um nome genérico; em (08), no entanto, é um frade, a quem ele se dirige na primeira décima por "reverendo": "Reverendo Frei Sovella,/ saiba vossa reverencia” e o tratamento honorífico reaparece na abertura da segunda: "Se està vossa reverencia / sempre a janella do coro”.

A partir dessa constatação, fui em busca da obra completa de GM (consultei a organizada por James Amado, 2. a edição, de 1990), na qual Miécio Tati, responsável pela revisão e atualização ortográfica da primeira edição das obras de GM, em 1969, diz o seguinte, a respeito do uso do pronome você:

8. Atualizamos a grafia de você (em lugar de vossê, como está nos códices - aliás vossé - , claramente indicando a contração de vosmecê, originária de vossa mercê); anotamos, não obstante,

${ }^{19}$ Embora a obra tenha sido publicada já em 2000, só recentemente consegui comprá-la. 
que você é ainda, ao tempo de Gregório, tratamento cerimonioso; (apud MATOS, 1990, p. 10).

Segundo Tati, pois, o pronome ainda teria uso cerimonioso no século XVII; no entanto, pelos exemplos acima, o seu emprego se contrapõe, num caso, (08), justamente a um pronome honorífico e, no outro, se dirige à massa da população (ou a um grupo de pessoas), depois do vocativo "minha gente". Fui, então, à cata de mais exemplos nos dois volumes em que está editada a obra poética do autor e verifiquei que ela estava organizada em tópicos, a partir do subtítulo "Crônica do viver baiano seiscentista”: I. O burgo (p.29-58); II. Os homens bons (p.59-396); III. A cidade e seus pícaros (p.3971174); IV. Armazém de pena e dor (p.1175-1228); V. O coronista reçusitado (p.12291245).

O que pude constatar é que em "O burgo" aparecem os pronomes tu e vós; em "Os homens bons", subdivido, em 1. As pessoas muito principais, é usado o vós para Deus, Jesus Cristo e Nossa Senhora; num longo diálogo entre a Alma e o Diabo, este emprega tu e aquela vós. Em 2. Pessoas beneméritas, apresenta-se o vós e em alguns poemas dirigidos/oferecidos à Princesa D. Izabel, Luiza, Josepha, usa o tu (no nascimento, em 1669); mas, por ocasião da sua morte em 1690, emprega o vós. São empregadas várias formas honoríficas na seção 3. Homens de Bem: tu e vós ao governador Braço de Prata (alcunha que a Antonio Luiz da Camara Coutinho deu GM, que também apoda de Tucano e fanchono), além de Vossa Senhoria, Vossenhoria, Sua Senhoria; vós para o Conde do Prado, filho do mesmo governador. E aí, no "retrato" que faz do governador, o poeta, depois de se referir de várias maneiras ao tamanho do nariz do governador, se dirige diretamente ao órgão:

(10) Você perdoe, / nariz nefando, / que eu vou cortando, / e inda fica nariz, / em que se assoe. / Ao pé da altura / no naso oiteiro, / tem o sendeiro, / o que boca nasceu, e é / rasgadura. / Na gargantona / membro do gosto / está composto / o órgão mais sutil / da voz fanchona. (MATOS, 1990, p. 184)

Parece difícil atribuir tom cerimonioso ao você nessa passagem, mesmo no século XVII. Além disso, Tati não menciona a partir de que fontes teria se fundamentado para fazer aquela assertiva, nem o que significa "cerimonioso" para ele: em relação ao tratamento mais íntimo, tu/vós, ou ainda com valor de honorífico?

Mais adiante, ainda na mesma seção, numa peça que diz respeito a uma pendência entre o vigário da vila de S. Francisco e um ourives, por causa de uma "mulata, que se dizia correr por sua conta”, o autor põe você na boca de um personagem, conforme o verbo dicendi que acompanha a fala (11) e, em (12), uma chamada direta ao ourives, censurando-o e aconselhando-o, com o vocativo Senhor:

(11) Naquele grande motim,/ onde acudiu tanta gente./a título de valente/ também veio valentim:/ puxou pelo seu faim,/ e tirando-lhe a barriga,/ você se quer, que lho diga, disse ao Ourives da prata,/ na obra desta Mulata/ mete muita falsa liga:/ Briga, briga. ( MATOS, p. 217)

(12) Senhor Ourives, você/ não é ourives da prata?/ pois que quer dessa Mulata, que cobre, ou tambaca é?/ Restitua a Moça, que/ é peça da Igreja antiga:/ restitua a rapariga,/ que se vingará o Vigário/ talvez no confessionário,/ e talvez na desobriga: Briga, briga. (MATOS, p. 218) 
Nas seções posteriores, prevalece o uso de vós e, mesmo quando a peça é dirigida a uma amada ou pretendida, dificilmente GM emprega o tu, que aparece mais frequentemente quando a invocação é para um elemento da natureza — sol, estrela — ou animal borboleta/mariposa, passarinho; obtendo, assim, conotações de puro lirismo. O tu aparece em umas poucas poesias amorosas e sátiras quando parece estar no limite da raiva ou da paciência em relação ao objeto do seu amor; mas, na seção 18, há duas abonações interessantes:

(13) Chegou, como tenho dito,/ e mesurado de pés/ abriu a urupema, e disse,/ sois vós, Dona Bersabé!/ Ao que ela respondeu logo,/ esta sou: entre você;/ ia ele já quase entrando,/ quando eu da rua gritei:/ "Tá, que não é cortesia/ entrar só vossa mercê, deixando-me a mim na rua,/ que de inveja morrerei."/ "Também você tem licença/ (me disse a Moça) porque/ onde há lei de cortesia/ não val comigo outra lei." (MATOS, p. 789-790)

(14) Entrou uma linda Moça,/ que mora logo através,/ pela porta do quintal,/ traidoramente fiel./ Fizemos-lhes as reverência,/ e ela com gentil prazer/ nos disse "as de vossarcedes,/ e nos as de vossarcê." Foi-se a ela o meu amigo/ (MATOS, p. 790)

Em (13), o poeta se dirige ao amigo que o acompanha, usando vossa mercê; a moça, de dentro da casa, responde ao amigo do poeta que ele podia entrar, usando o você e, depois de interpelada pelo poeta, através do amigo, dirige-se também a ele por você, invocando a lei da cortesia. Podemos pensar aqui que um tratamento vós ou tu, pela dama, seria inadequado e, nesse sentido, o você poderia ser considerado menos íntimo, para se dirigir a dois homens que chegam juntos. As outras ocorrências, em (14) vossarcedes / vossarcê - , são singulares, no sentido de que parece serem construídas sobre o modelo espanhol que levou a usted: vuestra(s) mercede(s), mas com a redução que ocorreu no português, vossarcê !

Ainda com relação à questão de o você ser cerimonioso, examinamos o que um seu conterrâneo e contemporâneo ${ }^{20}$, Nuno Marques Pereira (1652-1731), que escreveu uma obra intitulada Compendio narrativo do peregrino da América..., publicada em 1728, utilizou como formas de tratamento. Os dois volumes da obra contêm a "[...] narrativa do percurso do peregrino no espaço do nordeste brasileiro, transmitida através do diálogo com o ancião, símbolo da experiência humana.” (ALMEIDA, 2003, p. 327). Nessa viagem imaginária, aparecem vários diálogos com personagens de vários extratos sociais. Os tratamentos que predominam nessas conversas, carregadas de preceitos

\footnotetext{
${ }^{20}$ Gregório de Matos é objeto de referência de Pereira, no volume 2. Primeiro, quando narra um fato ocorrido no Terreiro de Jesus, com um sujeito denominado João Magano: “A este propósito de risadas vos contarei um caso, que vi acontecer. Havia um homem assistente na cidade da Bahia, chamado João de Araújo: vulgarmente o appelidavam por João Magano, por ter sido do congresso do Doutor Gregorio de Mattos, que costumava levar-lhe os alvitres, e contar-lhe os successos, que aconteciam na cidade, para os compor em versos. O qual homem morava em umas casas no Terreiro de Jesus entre o collegio e São Francisco.”(PEREIRA, , vol. 2, p. 111-112). Segundo, ao contar uma história acontecida com o próprio GM: "Ao doutor Gregorio de Mattos succedeu na cidade da Bahia, andando passeando no adro da igreja do Collegio dos Padres da Companhia, vir um homem desafiá-lo, por lhe ter feito uma satyra picante; e depois de várias razões, com que o desafiou, lhe disse que descesse para o terreiro [de Jesus], para com elle pendenciar, chamando-lhe cobarde. Responde-lhe o doutor: E quando lhe mandei dizer a vossa mercê que era valente? Riram-se os circumstantes, que presentes estavam, e o homem se foi corrido, e desconfiado.” (PEREIRA, vol. 2, 1939, p. 179-180).
} 
morais e religiosos, são o vós, tanto do peregrino para homem(ns) ou mulher(es), como destes(as) para ele e, eventualmente, em alguns diálogos apresentados nas histórias que usa para ilustrar determinado ponto de vista, ou preceito moral ou religioso, o Vossa Mercê (vol. 2, p. 157, 170, 171). Assim, a obra do padre Pereira, de cunho moralizante e exemplar, apresenta somente fatos educadores e norteadores do percurso terreno, de respeito ao seu semelhante e de bom comportamento na vida, almejando, como fim, a preparação para a salvação eterna.

Para situar o autor na sociedade do seu tempo, vejamos o que diz Almeida (2003, p. 215-216) sobre Gregório de Matos Guerra:

Filho de pai português, oriundo de família nobre de Arcos de Valdevez, Viana do Castelo, e de mãe brasileira, senhora de engenho de considerável fortuna, teve como irmão frei Eusébio de Matos. Fez os estudos preparatórios no colégio da Companhia de Jesus na Baía [sic], partindo em 1652 para Portugal, a fim de frequentar a Faculdade de Leis da Universidade de Coimbra, na qual se formou em Direito Civil e Canônico, no ano de 1661. Fixou-se em Lisboa, onde casou e viveu cerca de vinte anos, tendo exercido a advocacia e o cargo de juiz do crime e dos órfãos. Ganhou forte reputação como jurista, o que levou à promessa da sua designação para desembargador da Casa da Suplicação, lugar nunca atingido, pois na Corte houve influências em seu desabono, provavelmente devido a ter atingido com ditos mordazes pessoas ligadas ao círculo de D. Pedro II. Na fase coimbrã era já considerado "refinado na sátira", estilo que sempre manteve e lhe granjeou inimizades, levando-o a optar pelo regresso ao Brasil. Na Baía, debaixo dos favores do Arcebispo D. Gaspar Barata, foi nomeado, em 1679, desembargador da Relação eclesiástica e, dois anos mais tarde, apesar de apenas ter ordens menores, vigário-geral com murça de cónego e tesoureiromor da Sé Catedral. Os cargos desempenhados em nada o limitaram nas sarcásticas críticas dirigidas a inúmeras personagens da sociedade local, probatórias do seu estro satírico e cumulativamente de um certo menosprezo pela mentalidade colonial. A recusa em receber ordens sacras e a morte do seu protector, em simultâneo com diversas discórdias com o clero local, conduziram à sua deposição das funções que ocupava. Voltou à profissão de advogado e casou, em segundas núpcias, com uma bela viúva sem fortuna, Maria de Povos, musa inspiradora de alguns de seus poemas, mas com quem não deixou também de se envolver em desavenças. Foi durante a permanência na Baía que produziu a maior parte da sua obra, a qual permaneceu inédita durante largo período de tempo, tendo, na época, a sua divulgação sido feita através de folhetos avulso [sic] e por transmissão oral. A causticidade dos seus versos, bastante populares, pois muitos deles incidiam sobre factos concretos relacionados com questões de imoralidade ou de abusos do poder, não se coibindo de atingir altos dignatários, valeu-lhe o epíteto de Boca do Inferno e o forte desagrado do governador D. João de Lencastre, que o fez deportar para Angola, onde continuou a exercer a advocacia, agindo com tal mérito que 
o governador dessa colónia lhe assegurou o regresso ao Brasil, chegando em 1695 ao Recife, cidade em que veio a falecer no ano seguinte. Espírito boémio, inquieto e extrovertido, umas vezes afável, outras polémico e agressivo, teve uma vida repleta de mutações, acabando por morrer na pobreza quando nasceu na abastança. Na espontaneidade e brejeirice, tem na tradição oral do Brasil semelhança com Bocage em Portugal, até no domínio do anedotário, tornando-se difícil distinguir, a partir de certo momento, o que foi produção do poeta do que já é imaginação e criação populares. Apesar de ter passado larga parte da sua vida em Portugal, os temas dominantes nos seus poemas referem-se, no essencial, à realidade da sua terra de origem, pelo que deve ser fundamentalmente considerado um poeta do Brasil, havendo mesmo quem lhe conceda o privilégio de ter sido o iniciador da poesia lírica brasileira. A obra de Gregório de Matos, como muitas vezes é referenciado, enquadrável na estética barroca, mas com grande força expressiva, não se confinou à sátira, mas estendeu-se à poesia erótica e sacra e nas diversas vertentes foi libertina, contestatária e espiritualista.

A reprodução das biografias, embora longa, se faz necessária para verificarmos que ambos os autores brasileiros têm semelhanças na sua trajetória, física e intelectual. Tanto Gregório de Matos como Domingos Caldas Barbosa são filhos de português com brasileira e africana, respectivamente. Vivem um tempo no Brasil e depois seguem para o reino, para estudar em Coimbra (como, aliás, muitos brasileiros dos dois séculos, incluindo os inconfidentes), onde estudam Cânones. Depois dos estudos, vivem na corte. Se o músico permanece por lá e lá morre, Gregório de Matos volta ao Brasil, onde produz a maior parte de sua obra e consegue ser degredado para Angola, em 1694, de onde volta praticamente para morrer em Recife, em 1695. A produção da obra num dos autores é feita em Portugal; a do outro, majoritariamente quando está de retorno no Brasil. Não se conhece obra publicada do Lereno antes de sua permanência na Corte. De Gregório de Matos se sabe que grande parte da sua obra andou circulando em folhetos e foi de grande popularidade. Lereno escreveu cantigas e lundus, sendo satirizado na Corte, onde fazia sucesso, por causa da sua cor. Peres e La Regina (2000, p.17) afirmam que GM era "bem nascido, (e não mulato, como dizem), rico, de clã poderosa”. E trajetória semelhante teria tido o padre Nuno Marques Pereira, nascido em Cairu, Bahia, e supostamente falecido em Lisboa.

Por conseguinte, se poderia questionar se o uso de você por GM e Lereno seria decorrência de uma permanência em Lisboa ou, de fato, já haveria o uso de você tanto do lado de cá como de lá do Atlântico. Contra a primeira hipótese há, primeiro, o fato de que, se GM fazia sátiras a gente de variada categoria social, não poderia empregar um termo cujo significado e emprego fossem desconhecidos de todas as camadas da população da Bahia da época, pois o perfeito entendimento da mensagem é condição sine qua non para uma sátira atingir o seu alvo. Também é relevante o pouco uso que o poeta faz do pronome tu, para se afirmar que o pouco uso de você seria em razão de uma predominância do tu ou do vós.

Quanto a Lereno, se escrevia músicas (sobretudo cantigas e lundus) retratando fatos e gente do Brasil (mulatas, p. ex.), não poria na boca das personagens um pronome que 
não espelhasse um uso que caracterizasse a gente brasileira. Como ele mesmo afirma, na quadrinha:

Não é do Tamise um cisne / Quem vai soltar doce canto / Brasileiro papagaio / D’arremedo a voz levanto.

em que responde ao insulto que lhe dedicou Felinto Elíseo, nesta “estrofe desaforada”:

Os versinhos anões e anãs Nerinas / Do cantorino Caldas, a quem parvos / Põem a alcunha de Anacreonte luso, / E a quem melhor de Anacreonte fulo / Cabe o nome; pois tanto o fulo Caldas / Imita Anacreonte em versos, quanto / Negro perú na alvura o branco cisne.

contenta-se, "bem se vê, com ser "papagaio” e nada mais”. É assim que Assis Barbosa (1944, p. XIX) descreve o comportamento do músico na Corte: ele seria o papagaio que imita ("d'arremedo") exatamente o que ouviu na fase brasileira da sua vida... E são muitas as cantigas e lundus da Viola de Lereno em que ele emprega o você(s), de maneira consistente, não sendo aquela citada por Nascentes uma ocorrência única, isolada. Assim, podemos advogar pela hipótese de que o pronome você fazia parte da vida e da sociedade de ambos os lados do Atlântico, pelo menos desde o século XVII.

E se Pereira não empregou o pronome na forma contracta, não é talvez porque não o empregasse ou ele não estivesse "disponível” na língua escrita do seu tempo: o seu estilo é pomposo, apesar de pedir ao leitor (a quem trata por tu) que não note o seu "estylo humilde"... Questão de avaliação individual? Ou de "salvar a face”, como dizem os etnógrafos da fala? A diferença entre Pereira e seu coevo GM é que este ousou (felizmente, para a posteridade) retratar, por escrito, aquilo que se empregava na língua no seu tempo.

\section{DATAÇÃO DE SENHORITA}

Lendo a obra do Abade de Jazente (1719-1789), me deparei com algumas ocorrências do substantivo senhorita (Poesias, 1837) que, até então (século XVIII), não havia flagrado. Ao consultar o dicionário Houaiss (p. 2546), verifiquei que, na datação proposta no verbete "senhorita", ele consignava a de uma de suas fontes, o Novo Dicionario Critico e Etymologico da lingua portuguesa, de Francisco Solano Constancio, publicado em Paris, em 1836. Assim, podemos recuar em pelo menos meio século o uso dessa forma, pois a obra do Abade de Jazente, em que senhorita(s) aparece, é, originariamente de $1787^{21}$. Ela teria vindo concorrer com menina? Vejamos como era o seu emprego:

(15) Basta-me só que ás vezes nas vizitas/ $\mathrm{As}^{22}$ vejão Petimetres namorados,/ As oução sem desprêzo as Senhoritas. (Poesias, p. 10)

\footnotetext{
${ }^{21}$ Em Poesias, página 09, lemos: "Em 1787, no prólogo do 2. ${ }^{\circ}$ Tomo da sua edição das Poesias ... referiase assim o editor Bernardo Antonio Farropo: [...]”

22 O referente desse As é “clausulas escritas” (isto é, as poesias do autor), que aparece antes no soneto.

Veja-se também que os clíticos dos dois versos finais vêm em próclise...
} 
(16) Enquanto na assembléa a Senhorita / Gasta a jogar parte da noite escura / E de outra banda o Petimetre apura // Huma Dama de honor, a quem visita. (Poesias, p. 228)

Talvez a criação de senhorita tenha sido decorrência da expansão e do abuso dos títulos honoríficos, a partir sobretudo do período da Restauração (1640), o que muitos autores do século XVIII vão satirizar, inclusive o Abade de Jazente, como vemos nos dois tercetos de um soneto, em que justifica porque ele quer ir morar na aldeia (Poesias, p. 95):

Aqui que mora a paz, vive a innocencia,

Aqui na vossa amavel companhia [das Musas]

Dos annos quero passar a decadencia.

E a faltar-me outro bem, me bastaria

O naõ soffrer aqui tanta Excellencia,

Nem me aturdir com tanta Senhoria. (negritos acrescentados)

Em relação às mulheres, como parece não ter havido outro tratamento posterior àquele dos poetas da Idade Média - Dona, Senhora, percebe-se que, em função das mudanças havidas na sociedade portuguesa, com a introdução de alguma permissividade — jogos, bailes, assembléias —, advindas de um verniz de civilidade decorrente da riqueza pósdescobrimentos, que permitia um luxo até então impossível, as moças solteiras careciam de forma adequada para serem tratadas. O Abade, em um dos seus sonetos, nos revela que até as campônias reclamavam o seu quinhão de "cortesia”:

O Barbeiro he Doutor na sua Aldêa

O Lavrador Morgado, o Cura Abbade;

E a Sobrînha, imitando as da Cidade;

Quer Senhorîa, e Dona se nomêa.

Que a sociedade havia se modificado, parece não haver dúvida (cf. Poesias, p. 16: "Em vez de amor, nos diz galanterîa" ou p. 17: "E tem-se feito em tudo tal mudança, / Que até por novo estylo se namóra”); emprestemos de novo a palavra do Abade de Jazente, que com tanta propriedade satiriza a situação do Portugal da sua época (Poesias, p. 21; negritos acrescentados):

Portugal, que era rûstico algum dia, Incivil, trapalhaõ, mal amanhado, Está (graças á França) taõ mudado, Que o mesmo ja naõ he, que ser sohîa.

A lingua, o trage, o trato, a grossarîa Dos antîgos costumes tem deixado: He todo doce, he todo concertado; E parece outro sua Senhorîa.

Conversa, jóga, dança; e o novo enleio; Que entre os dous sexos logra, he taõ decẽte, Que á sátira mordaz tem posto hum freio.

Vive agora hum marido mais contente:

Hum Pay sem susto; e todos sem receio:

Ditosa condiçaõ! Ditosa gente! 
Por isso, nessa "nova” sociedade, se impunha criar uma denominação para as jovens mulheres que já não agiam como antigamente, gozavam de uma certa liberdade e que não podiam mais ser chamadas de donas ou senhoras ...

\section{DATAÇÃO x ESCRITA: $O C \hat{E}$}

Se datar uma forma é importante por uma série de razões, não podemos esquecer, em nenhum caso, que, para épocas pretéritas, a única fonte é a escrita. E aí se coloca o problema de se saber em que medida a fonte escrita espelha a data ou período em que uma palavra começou a ser usada. A escrita não pode ser, em qualquer circunstância, o fiel da balança, pela simples razão de que uma palavra pode levar muito tempo até ser admitida no registro escrito. Todos nós, linguistas, falamos hoje de alternância tu/você no PB; mas continuamos a empregar a forma você e não cê, estágio de há muito presente em diferentes dialetos do PB. Assim, se os nossos trabalhos acadêmicos viessem a ser fonte exclusiva para algum pesquisador de séculos vindouros, ele chegaria à conclusão de que não teria existido a forma cê antes de ela ter aparecido num texto escrito com foro de literatura geral, na boca de personagens de classe média. Essa forma reduzida, ainda que mencionada nos trabalhos sociolinguísticos, seria imputada somente à plebe, ao "zé-povinho", às camadas iletradas da população, embora todos a usemos em situações mais (ou menos) informais (mesmo se, indagados, em avaliação subjetiva juremos que não usamos jamais o cê!).

Além disso, cada autor, cada indivíduo, carrega em si boa parte da língua anterior ao período em que adquiriu o vernáculo, seja por transmissão dos pais e avós, com quem convive bom tempo, seja por aquisição na escola (na qual ingressa cada vez mais cedo), onde toma contato com outras variedades, mais formais, que contêm em si muitos arcaísmos - lexicais e morfossintáticos (convém lembrar que as abonações de uso ainda remontam aos clássicos da língua).

Dessa maneira, fazemos nossas as palavras de Bally (1965, p. 71)

La langue écrite ne peut donc faire découvrir les véritables caractères d'une langue vivante; car, par son essence même, elle est en dehors des conditions de la vie réell; elle ne peut non plus donner l'image authentique d'un état de langue, puisque, par nécessité et par privilège, elle vit à la fois dans le passé, le présent et l'avenir, et que le même auteur, dans une même page, peut être en avance ou en rétard sur l'évolution de la langue parlée ${ }^{23}$. [retirar a parte com contraste amarelo pq. localizei o original, conforme referência acima; (você tem que editar a referência bibliográfica, no final: está contrastada em amarelo)!(citado por Serafim da SILVA NETO, 1940, apud PINTO, 1981, p. 367)

\footnotetext{
23 “A língua escrita não é capaz, portanto, de revelar as verdadeiras características de uma língua viva; pois, pela sua própria natureza, está fora das condições da vida real; além disso, ela não pode fornecer a imagem autêntica de um estado de língua, visto que, por necessidade e por privilégio, ela vive ao mesmo tempo no passado, no presente e no futuro e um mesmo autor, numa única página, pode estar avançado ou atrasado em relação à evolução da língua falada.”
} 
Por tais características, a língua escrita demora por incorporar os avanços já consagrados na língua falada. Quando escrevemos, exercemos uma autocensura sobre o que pode e o que não pode ser escrito, por mais que defendamos modificações, que defendamos as mudanças e as pratiquemos quando falamos, como, por exemplo, comenta Manuel Bandeira, falando sobre o “idioma nacional dos brasileiros”:

\begin{abstract}
Vamos deixar disso. O povo faz a língua, as classes cultas se servem dela com escolha e apuro, finalmente os escritores a empregam artisticamente. Alguns modernistas tomaram esta empreitada de ridículo. De ridículo! ... Seria melhor que fosse João Ribeiro quem começasse. Ele pensa assim (Vejam o volume A língua nacional). Mas, não sei por que, nunca escreveu assim. (BANDEIRA, 1926, apud BATISTA et al., 1972, p. 273-274, apud PINTO, 1981, p. 210)
\end{abstract}

A partir dessas considerações, quando deparamos com uma forma escrita, que não o tinha sido antes, temos que, forçosamente, remeter a sua criação/ocorrência a um momento muito mais anterior na história da língua. O período de variação que antecede uma mudança pode ser muito longo... Assim, o registro de uma forma na escrita, na literatura, é significativo, no sentido de que, para além de nos balizar a época de uso, espelha uma subconsciência do autor que, ao utilizá-lo, (i) já teria expurgado, quem sabe, um eventual preconceito quanto à validade da forma; ou, (ii) retrataria uma avaliação da forma (como indicador, marca, estereótipo, cf. WLH, 1968) pela sociedade e por si próprio. No mínimo, colhemos aí um indício para analisarmos a questão da avaliação e da implementação (cf. WLH, 1968) de uma forma linguística, etapas tão importantes no estudo das mudanças em uma língua.

Há uma situação bastante interessante na literatura brasileira: existe uma querela para se definir quem foi o primeiro autor regionalista. O embate fica entre o mineiro Afonso Arinos (1868-1916), que teria publicado em 1898, em formato de livro, uma obra regionalista (reunindo contos, segundo o autor, produzidos entre 1888 e 1895), em Pelo Sertão, e o paulista Valdomiro Silveira (1873-1941), que teria estampado seu primeiro conto, Rabicho, em 1891, no jornal Diário Popular, em São Paulo e cujo primeiro livro - Os Caboclos - só teria saído a lume em 1920, reunião de contos produzidos entre 1897 e 1906, exceto dois, conforme nos relata Agenor Silveira no prefácio da primeira edição da obra (datado de 23.07.1920 e dirigido a Monteiro Lobato, reproduzido em Silveira, 1962: IX-XI). Como os dois autores, um mineiro - Arinos, e um paulista Silveira, retratam personagens de uma região em que teria continuado e estendido o processo de gramaticalização do você (utilizado ao lado de vosmecê, mecê, vassuncê, vancê, vacê), dando origem à forma reduzida ocê, hoje cê (cf. RAMOS, 1997), seria de esperar que ocê aparecesse já, consistentemente, nas duas obras. Por quê? Porque eles retrataram, ambos, situações de vida corriqueira dos caboclos, dos roceiros - as suas personagens. Mas por que esperar a ocorrência da forma ocê? Porque ela já existiria na região, como podemos ver pelo trecho abaixo, retirado de A Carne, de Júlio Ribeiro, 
que dedicou o seu romance (que se passa no interior de São Paulo ${ }^{24}$ ) ao pai do Naturalismo, Émile Zola ${ }^{25}$ :

Os negros ergueram-se todos, reverentes.

— Zelómo, disse Joaquim Cambinda, ussê pensô bê nu quê ussê vai fazê, lapássi?

— Pensô, mganga.

- Intonsi, ussê qué mêmo si rissá ni rimanári ri San Migué rizáma?

- $\begin{gathered}\text { Qué, }_{\text {mganga. }}{ }^{26} \text { (RIBEIRO, 1946, p. 111, negritos } \\ \text { acrestados) }\end{gathered}$

A respeito desse trecho, Nascentes (1953, p. 15) diz ser ele um espécime de dialeto crioulo, em nota à sua asserção "Um espécimen de tais dialetos [crioulos] tinhamos na linguagem dos pretos minas, hoje quase totalmente desaparecida."

À parte a discussão sobre ser isso, ou não, um dialeto crioulo, nos interessa considerar que a forma contracta ocê (ussê, com alçamento da vogal média posterior átona, reproduzindo outro traço da linguagem da região, pelo menos a parte mineira) já estava, evidentemente, em uso corrente na segunda metade do século XIX, pois, se Júlio Ribeiro publicou seu livro em 1888, retratou a fala de um preto velho, feiticeiro. Se nos ativermos à técnica de análise em tempo aparente, tal como fazemos nas análises sociolinguísticas, poderíamos remontar o uso ao tempo da infância do preto velho, ou seja, inícios do século XIX; porém parece que a forma não se restringiria somente ao falar exclusivo dos escravos, como Nascentes deixa entrever, pois Valdomiro da Silveira a emprega nos contos d'Os Caboclos, na fala de pessoas comuns do sertão, em (17) e $(18)^{27}$.

(17) — 'ocế ${ }^{28}$ 'tá queixosa de mim, 'tá admirada? 'É porque 'ocê não conhece o coiração dum home' da minha casta! [...] Agora 'ocê fica 'maginando que o meu coiração é duro e 'tá fechado[...] e 'ocê visse por dentro o meu coiração, minha dourada, 'ocê havéra de ver que o amor é que faz a gente rúim [...] (Velha dor, p. 43)

\footnotetext{
${ }^{24}$ Os protagonistas do romance, Lenita e Barbosa, se tratam mutuamente por você.

${ }^{25}$ Conforme consta da carta dirigida ao escritor francês, em 25.01.1888, reproduzida em Ribeiro (1946, p. 07-08).

${ }^{26}$ Na edição que consultei, há uma nota, traduzindo o trecho e explicando o significado de mganga:

“(1) “- Jeronymo, você pensou bem no que você vai fazer, rapaz? / — Pensei, mestre. / — Então você quer mesmo alistar-se na irmandade de São Miguel das Almas? / — Quero, mestre.”

A palavra mganga é termo africano: significa senhor do tempo, distribuidor da chuva: e, por extensão, theologo, sacerdote, mestre."

${ }^{27}$ Estranhamente, porém, nos contos de Leréias ( histórias contadas por eles mesmos), publicadas em 1945, aparece a consignação de um único emprego de ocê. Trata-se de um trecho em que o protagonista "fala com os seus botões”, antes de ir para casa, na noite que acabou por esfaquear e matar a mulher, Ogusta: “- Agora, Venancinho, chegou a sua vez de dar a casca: 'ocê não tem por que ficar ansim agoniado, e 'tá ansim, 'tá morto!” As formas mais numerosas, são, em ordem decrescente, você(s), vancê, vassuncê, suncê e mecê. De ocorrência única, além do ocê, são: vós e vacê.

${ }^{28} \mathrm{O}$ apóstrofo é empregado sistematicamente pelo autor, desde a primeira obra, para indicar a supressão de fonema(s).
} 
(18) (Maria Claudina p/ Romana, preta velha): —É 'ocê, Rumana? 'ocê não acha o Grande muito bom de coiração e de cabeça? [...] (Romana p/ m. Claudina): Nem fale, nhá Clodina! 'ocê 'tá um brinco, de linda! (Missa de Páscoa, p. 4647)

Em (17), Bernardão se dirige, com remorsos, à mula, que fora sua companheira de infortúnios, mas muito exigida por ele no caminho, acabara de morrer. Em (18) vemos que tanto a sinhá como a preta velha empregam o ocê.

Em (19), vemos uma distribuição social no uso de vancê (do Zeca Estevo para o velho feiticeiro), o que indica tratamento respeitoso para os de mais idade e posição; e de variação no uso de ocê/você por parte do velho "prático de fama” para o Zeca Estevo. Parece que o uso de ocê está ligado à reprimenda que lhe dirige o velho que, depois, continua, aparentemente em tom mais solene, argumentativo, com o você, para contestar o aparente desconhecimento do caboclo de que estaria acometido de lepra:

(19) Antão, meu patrão velho, o que é que eu tenho? [...] / - O mal. / - O mal? Vancê 'tá caçoando! / — Caçoando 'tá 'ocê, menino! Pois antão você, quando veio aqui, não sabia já que 'tava camunhengue? (Camunhengue, p. 58)

Assim, com esses empregos, podemos vislumbrar quais seriam as formas mais íntimas (ocê/você) e as mais distanciadas, respeitosas: vancê (talvez vacê), vosmecê, o senhor, no final do século XIX, início do XX, no sertão.

E, estranhamente, ocê não aparece na primeira obra do outro regionalista, o mineiro: Afonso Arinos consigna somente você(s) e vossemecê! Além disso, é bastante copioso o emprego de tu, com a concordância verbal canônica, isto é, com os morfemas número-pessoais previstos na gramática tradicional. Na segunda obra que publica, Jagunços, ainda em 1898, também não aparece ocê; mas registra, além daquelas acima, vancê, vacê(s) e vassuncê (ARINOS, 1969, p. 238 e 261, respectivamente), que também aparecem em Ouro! Ouro! , novela incompleta (escrita, talvez, em 1904).

Em O contratador de diamantes, de 1917, registra você, vancê, vosmecê, Vossa Mercê e V. S. ${ }^{\text {a }}$, além do uso de tu sem concordância, na representação do Congado: "1. ${ }^{\text {o }}$ Negro: - Tu vai pagá, Juda do Inferno, o que tu fêz a Noss'sinhô!” (ARINOS, 1969, p. 584, negrito acrescentado). É relevante acrescentar que Arinos situou a época da peça teatral em 1751-1753. Só na obra $O$ mestre de campo, de 1918, é que flagramos a primeira ocorrência do pronome com aférese da consoante inicial (20): oncê, na boca da Maria, mucama da casa, que responde à Nhanhã, que lhe havia perguntado: "Você não disse que Nhô Juca não estava aqui?”. Veja-se que, em termos de implementação, a forma já estaria assentada na língua; contudo a avaliação que transparece é a de que as pessoas socialmente mais elevadas ou com alguma instrução (caso da Nhanhã) só empregariam a forma plena, você, e seria apanágio da classe social mais baixa, servil ( a mucama) o uso da forma aferética.

(20) Disse, Nhá-sim! Mas os home diz que qué falá c’oncê mêmo. (ARINOS, 1969, p. 442)

E ocê só vai figurar em Histórias e paisagens, de 1921, na história O Mão Pelada (ARINOS, 1969, p. 811-817), mas na boca de dois negros: 
(21) João Congo: - Quê dê a batata p'ra comê, Quindanba? / Quind.: — Não tem não. Tem só mandioca puba, pr’a comê co melado. Oia a cabaça ali dependurada. / João Congo: - Ocê não quis falá do guampo de ristilo, Ah! nêgo veiaco. / Quind. - Iô tá lembrado também do que ocê tá pensano. Cruz, Ave-Malia! Nossinhô do céu me livre do "Mão Pelada”! (ARINOS, 1969, p. 812)

\section{IMPLEMENTAÇÃO E AVALIAÇÃO}

E para que serve saber a data do primeiro registro de uma palavra na escrita? Não é, evidentemente, só para constar como certidão de nascimento: a datação nos fornece um dado importante para concebermos como a avaliação da linguagem era percebida pela sociedade do seu tempo. Podemos reunir, indiretamente, dada a quantidade de ocorrências de uma forma ${ }^{29}$, os elementos contextuais de sua aparição na escrita, pois, até o período em que apareceu o gravador e pudemos registrar o oral, temos que nos fiar pelos registros escritos. E esses, dada a própria natureza da escrita, a de ser conservadora, pela força da prescrição dos mecanismos reguladores - escola, jornal, literatura ${ }^{30}$, dicionários - somente retrata, e tardiamente, as mudanças já ocorridas. Dificilmente vamos ter acesso ao processo de variação que precedeu à mudança, por isso é importante conseguir todas as abonações possíveis, a fim de se poder tentar reconstituir o percurso de uma forma linguística através da história.

Conforme vimos acima, há uma dificuldade muito grande de se saber se você era respeitoso ou não na obra de GM; contudo, a coisa não fica muito diferente quando queremos saber a respeito das primeiras ocorrências de ocê, mais próximo de nós. Como a escrita, até muito recentemente, era apanágio de um número reduzido de pessoas $^{31}$ - dominar o código escrito, em termos de produção, exige escolaridade elevada —, a maior parte das pessoas não tinha "voz", nem vez, na escrita. Podiam até escrever, mas o faziam de forma não aceitável pelo órgão regulador, a escola. E mesmo a linguagem dessa instituição tem, ainda, como modelo absoluto, os autores clássicos, cuja língua refletia a sua sociedade, o seu intervalo histórico, não o nosso nem o dos vindouros. Assim, o nosso "modelo" de língua escrita era/é o de uma língua arcaizante, conservadora, e é nessa perspectiva que temos de encarar a datação do registro escrito. Sobre o duplo aspecto da língua literária - conservador e inovador —, assim se expressava Serafim da Silva Neto (SILVA NETO, 1977, p. 22) em 1950:

\footnotetext{
${ }^{29}$ Consignemos aqui o que disse Serafim da Silva Neto, em 1950, a propósito do que é necessário para se considerar um fato de língua como normal: " $b$ ) sabendo-se que o normal é o fato que se repete maior número de vezes - estabelecer, primeiro para cada autor e depois para cada século, quais os fatos normais e quais os que refletem peculiaridades estilísticas deste ou daquele escritor. O que é normal numa época pode não ser outra, e vice-versa.” (SILVA NETO, 1977, p. 217)

${ }^{30}$ Retomemos Silva Neto (1977, p. 216): "Em primeiro lugar julgava-se que a verdadeira língua era a dos escritores, e que o povo, em sua ignorância, a deturpava e corrompia. Escapava-lhes que a única linguagem que realmente existe é a linguagem viva do povo, que os escritores, com arte e gosto, burilavam e aperfeiçoavam. Não [os gramáticos] que a língua que julgavam deturpada era, precisamente, a matéria-prima com que se alçavam as grandes obras literárias. Finalmente, não levavam na devida conta que a língua não é uma obra feita e acabada, mas um elemento vivo e em perpétua agitação. Assim é que, para provar a legitimidade desta ou daquela palavra, desta ou daquela frase, citavam-se os autores dos séculos XVI e XVII!”

${ }^{31}$ Basta consultar um anuário do IBGE — Instituto Brasileiro de Geografia e Estatística — para vermos as altas taxas de analfabetismo no país, em diferentes épocas.
} 
A língua literária não é mera fotografia da língua falada, pois quem se mete a escritor está obrigado a ter instrução, a conhecer os princípios normativos do idioma.

Se ela, em grande parte, representa utilização artística da fala corrente, encerra também farta dose de elementos tradicionais, colhidos na leitura dos ótimos estilistas do passado.

Eventualmente podemos deduzir certos condicionamentos presentes na produção, como vamos ensaiar com o você $>$ ocê $>$ cêe, que pretende ser a conclusão deste artigo, mas que é somente a introdução para a outra etapa do trabalho sobre implementação e avaliação dos tratamentos em português.

Comecemos com Nascentes (2003 [1955], p. 440): ao arrolar as formas em que o tratamento vossa mercê "deturpou-se" [sic], o autor tece algum comentário avaliativo e alguma abonação. Elencando as formas em ordem alfabética, o cê parece antes do ocê:

Cê. Aparece numa frase típica do linguajar da malandragem. Quando um malandro se lembra de ameaçar outro, este responde: Cê é besta. Existe em Goiás: Seu moço, cê vai arretiranu. / Eu não queru mais lhi vê (folclore, apud José A. Teixeira, Estudos de dialectologia portuguesa — A linguagem de Goiás, p. 98). Forma aferética de ocê.

Mecê. [...]

Mincê. [...]

Ocê. Forma aferética de você, atribuída aos negros. (Serafim Silva Neto, Capítulos de História da Língua Portuguesa no Brasil, p. $60^{32}$ ). Eu a ouvi em Minas Gerais. Existe em Goiás. Sai daqui, seu fede, fede / Vai feder na mocetura. / Quando ocê em vida fede, / Quem dirá na sepultura? (Do folclore, apud A. Americano do Brasil, Cancioneiro do Brasil Central, p. 79). Aparece alternando com cê. Meu mano, meu camarada, / Tudo no mundo é assim: / Comigo ocê fala de outros, / C'outros cê fala de mim. (Do folclore, apud Ronald de CARVALHO, artigo "Um século de pensamento" In: Dom Casmurro de 1-7-39, p. 2)

Quando Nascentes diz que a forma cê aparece na linguagem dos malandros, está refletindo uma avaliação negativa da sociedade carioca dos anos 1950, em que vivia e cuja linguagem procurou descrever? A pergunta se justifica pelo fato de, ainda hoje, ligarmos a malandragem ao Rio de Janeiro... A seguir, ele afirma que cê existe em Goiás, mas não adianta a esse uso nenhum valor atribuível, positivo ou negativo. Simplesmente informa, ou fica na dúvida se ela teria o mesmo valor imputado na primeira abonação? Os malandros a que se refere Nascentes seriam os descendentes dos negros, a quem atribui a forma aferética ocê? Em Minas e em Goiás, ocê é empregado só pelos negros? Vemos que os exemplos citados por ele são, em geral, do cancioneiro popular, a que ele chama de folclore.

Pois de Goiás vêm abonações da forma ocê(s) na fala de roceiros e viajeiros. Trata-se de exemplos encontrados nos autores que compõem a Antologia do conto goiano, volume I

\footnotetext{
${ }^{32}$ Não consegui localizar essa referência de Serafim da Silva Neto, para obter maiores detalhes.
} 
(obras publicadas dos anos dez aos sessenta do séc. XX). O registro mais antigo ${ }^{33}$ é do autor Crispiniano Tavares (1855-1906), no conto "Quem semeia ventos colhe tempestade":

(22) O Pedrão gritou: — É assim memo canaia! Vim lá doutro mundo pra matá ocês tudo, sôs porcaria! (Antologia, p. 41)

(23) - Suspende aí, Pedrão. Eu num tô sabedor, nem a patroa. Nisto ela falou: Sô Pedrão, pro bem qui ocê qué a sua mulhé num faça mais fervença nem mal a meu marido qui fez uma doidura. Eu vou buscá o dinheiro todo, dois conto e quinhentos. A sua mula tá aí no currale e ocê vai imbora agora memo. Leva no cabresto a mula de sela do sô Heraqui qui eu dô pra você, [...] (Antologia, p. 41)

Pedrão (22) era um "campeador" que reaparece depois de, supostamente, ter sido executado por mando de sô Heraqui, que não queria pagar os vinte e cinco mil réis em que convertera a dívida; em (23), a patroa Rosalina era uma viúva "graúda da nota", com quem sô Heraqui (Heráclito Flaviano, dono de terras, assim chamado pelo Roge, o narrador da história, o eu de (23)) casou. Mas o sô Heraqui andou com a Rita do Pedrão, nas suas ausências e este, quando descobriu, fez um "arranca-rabo" e, finalmente, ficou assentado que, quando Heráclito "casasse, o Pedrão pudia também durmi com a mulhé dele.” A fala apresentada em (23) se passa quando o Pedrão vem, do além, cobrar a dívida... Verificamos, por conseguinte, que ocê podia ser usado, já, tanto por patrões como por empregados, pelo menos em Goiás.

Nos autores nascidos no início do século XX, dessa coletânea, os usos vão ser mais numerosos, o ocê sendo empregado em várias funções sintáticas, como no conhecido Bernardo Élis, nascido em 1915. Assim, constatamos que os usos das formas aferéticas do pronome são característica dos sertanejos goianos, homens e mulheres.

Em 1899 é publicado o livro Os roceiros, de Viriato Padilha (portanto, no ano seguinte ao de Arinos). Pois bem: no prefácio, o autor assim se expressa, localizando espacialmente o mundo da roça e caracterizando o caipira ou matuto ou tabaréu (negrito acrescentado):

mundo, no qual vamos fazer o leitor penetrar, começa um pouco além dos suburbios de nossas cidades, e estende-se até os mais remotos confins dos estados mais centraes do Brazil.

É o mundo dos roceiros, do povo rude e ingenuo das brenhas, dos campos, das mattas, dos sertões: é o mundo do caipira, do matuto, do tabaréo.

Foi n'elle que se inspirou este livro, com o qual pretendemos fazer para o Brasil o mesmo que o novellista A. de Trueba fez para a Hespanha, com os seus Cuentos Campesinos, pois o que subscrevemos ao titulo Roceiros, não passa de um feixe de narrativas singelas e mais ou menos episodiaes e interessantes, em as quaes apresentamos o caipira no desempenho das suas

\footnotetext{
${ }^{33}$ Se levarmos em consideração a técnica do tempo aparente, que considera a data de nascimento do autor/informante e não a data de publicação de uma obra (quando o corpus é escrito): no caso desse autor, a obra tem edição póstuma, de 1910.
} 
variadas funcções - fazendeiro, criador, tropeiro, vaqueiro, trabalhador agricola, autoridade policial, mestre-escola, curandeiro, etc.; e bem assim descrevemos as suas festas tradiccionaes, domesticas e publicas, estudamos os seus sentimentos, paixões, vicios e qualidades; copiamol-o na singeleza da sua rusticidade, nos seus costumes curiosos, nos seus ridiculos; finalmente, procuramos surprehendel-o em todas as suas feições pittorescas.

Foi esse o nosso intuito. Agora o publico que julgue si na execução da obra nos desviamos muito da méta desejada.

Viriato Padilha

(Annibal Mascarenhas)

A partir de Padilha, podemos constatar a amplitude da distribuição do que se chama, eufemisticamente, hoje, "homem do campo", a quem se costuma atribuir o uso das formas ocê/cê. A primeira delas, inclusive, é estereótipo do mineirinho. Como se terá originado esse estereótipo? Arinos, mineiro e retratando a sua terra, nos finais do séc. XIX, sequer menciona a forma nas primeiras obras e quando o faz, como vimos acima, já na segunda década do século XX, é de maneira bem restrita: na boca da mucama e dos dois negros.

Vejamos os pronomes empregados em Padilha (na ordem de aparição na obra) para se dirigir ao interlocutor: vomecê, você, tu sem concordância, ocê, vocemecê, V. S.a , vocês, vancê (este, em reprodução de texto do livro anterior do autor, Livro dos Phantasmas, s/d.). O ocê é empregado pelo Capitão Zezé, subdelegado da localidade, quando se dirige (24) à siá Carola ("uma mulata de sustancia”), que lhe leva e mata o galo de estimação, e a dois caipiras (25), os quais despacha para a guerra do Paraguai, por terem ajudado a comer o galo que a siá Carola "tinha emprestado" do delegado para tirar “delle geração com as suas galinhas”!

(24) Olhe, siá Carola, com qualquer outra pessoa, eu não faria isto, por preço algum; mas ocê manda, não pede. [...] — Em paga desse favor, ocê hade dar essa flor que tem no cabello. (O subdelegado na roça, p. 104)

(25) E tu, Piau, abre o oio comigo, sinão eu te mando jogá uma farda nas costa. Paraguay tá precisando de gente, e o que Sua Magestade Imperadô qué é mesmo desses vadião como ocê. [...] — Home, vocês já viram para o que havia de dar este sujeito! Sim, sinhô, ocê tá me sahindo um bom pastô, seu Piáu! E que verso botou elle na sua muié, Neco Torre? [...] — Você mesmo botou esse verso na muié do outro, Piáu? [...] — Quá! Ocês estão mas é percurando sarna p’ra se coçá; [...] Então ocês num sabe que na muié dos outros num se bota nada? Enfim, por esta vez eu dou ao desconto, porque, afinal, vocês estão pagos com o que fizeram um ao outro. (O subdelegado na roça, p. 104-111)

Nesses exemplos vemos também uma variação no emprego da forma plena e da forma reduzida, tanto no singular como no plural. Parece haver uma distribuição entre elas: quando o subdelegado assume um tom mais formal, de autoridade, quando divaga ou no interrogatório e na tomada de decisão, usa você. 
Um outro autor que retratou os caipiras, sendo ele mesmo de Tietê, no interior de São Paulo, vai mais longe nas abonações das formas que estamos estudando: trata-se de Cornélio Pires (1884-1958), em cuja obra vamos encontrar, finalmente, o registro de cê. E não se pense que o intervalo de tempo entre os primeiros escritores regionalistas e ele seja grande: em Patacoadas (1926), Cornélio Pires apresenta relatos e narra histórias:

(26) Viajando em 1906 pelo sertão de Paranapanema, encontrei um caipira endinheirado, que se lamentava de não conhecer S. Paulo. [...] - Pois perca o amor a uns cobres, embarque para a Capital e telegrafe avisando, que irei esperá-lo à estação. [...] Já meio esquecido do caipira, certo dia recebi o telegrama combinado. [...] À chegada do trem, notei grande algazarra junto a um vagão de segunda classe. [...] E os carregadores [italianos] empencaram em cima do caipira como formiga em mosca morta. [...] — Olá, Nhô Carrinho! O caipira me refugou, mas me reconheceu. — Ó! C’os diabo! Quaje num conheci oçê co'essa japona ... e, numa última reação: - Ô intalianada escamungada! Cês nunca viro baúr, diabo! (Um caipira em São Paulo, p. 25-26)

(27) Sai, Tigre! Cê num sabe que cachorro que morde padre vira cuzarruim? (Não esperou o café, p. 84)

(28) O que é isso, Filício! Cê bebeu tudo o meu vinho! — Uái! Cumo é que eu havera de bebê o meu sem bebê o seu! Mea meia garrafa tava no fundo ... (Argumento perfeito, p. 86).

(29) Vaceis viéro in má casião... A véia num tá aí... foi bigitá a mãe... [...] Mais vaceis hão de cumê os dois num prato só... Eu tenho munta réiva de lavá prato... (Eles se defendem, p. 86)

(30) Vá via.. vá via... Bradou o Battistini - Oceis no sabe o que ton dizeno! Quem se inventô os balone io les posso dizê! — Foi uno certo Bartolomé, qui móra na rua dos Gusmões... (Quem sabe, sabe!, p. 120)

(31) Argúa coisa ocê feis! Respondeu o carcereiro. — Ieu? Canié disse brocê! Ieu jura balabra de Deus num faz nada... Se tá falando mantira bóde cae raio brocê áagora mesmo... [...] — Alto lá! Precisa pagar $12 \$ 600$ de carceragem. Queee! Ocê berdeu o cabeça? Auande cê já viu desbôs breso baga danêro, tamben? (Fica Friquez, p. 126-127)

Em Cornélio Pires assistimos a uma generalização do uso das formas aferéticas, nas mais variadas personagens, ricas e pobres, nacionais e estrangeiras. Sim! Porque ele estende à boca de italianos (30) e sírios (31) as formas que deviam ser só nacionais e só dos caipiras... Mas como São Paulo era a cidade de confluência dos povos, por que motivo outras gentes não assimilariam aquilo que, aparentemente, muito mais gente brasileira, além dos matutos, já empregaria?

Mais ainda: o que ele também registra, no início do século, é a pronúncia já ditongada do pronome: vaceis e oceis... Aliás, a forma ditongada vanceis já tinha aparecido no primeiro livro — de poesias — publicado por Cornélio Pires, em 1910, Scenas e paisagens da Minha terra (Musa Caipira), rimando com treis e purtugueis:

(32) Nois num temo parente purtugueis, / nem mico, nem cuaty, nem capivára ... / Semo fio de Deus cumo vanceis! (Soneto A origem do caboclo, p. 32) 
Assim, em Cornélio Pires a avaliação dessas formas não é, absolutamente, negativa, pois ele registra um processo de ampliação no uso das formas aferéticas e ditongadas, nos dando pistas para estudarmos a etapa de implementação das variantes do pronome você no PB. Ele se preocupou, ainda, em registrar como os caipiras utilizam as variantes oriundas do vossa mercê, no final do Vocabulário (p. 159-177) que ele agregou à sua primeira obra, para os leitores não terem dificuldades com as palavras e expressões nela empregadas: "Entre os caipiras o tratamento é interessante, notando-se o vossa mercê com as seguintes alterações: vancê, voncê, vassuncê, você, mecê, suncê e ocê... (O vosmicê não é usado entre os caipiras paulistas).” (PIRES, 1921, p. 178)

Uma última observação, para a continuidade do estudo da implementação e avaliação dos tratamentos em português: fica evidenciado que os escritores paulistas (e goianos, como vimos acima) são menos preconceituosos que os de outras partes, no registro das formas aferéticas do você. Seria porque em São Paulo o falar caipira era autóctone, uma característica regional, por conseguinte, bem avaliada e aceita? Como pudemos observar, na coletânea $O$ conto do Rio de Janeiro, seleção de Magalhães Jr., editado em 1959, de autores nascidos no séc. XIX (escritores cariocas: entre 1838-1918 e fluminenses entre 1839-1865), não aparece consignada nenhuma ocorrência de ocê; só tu, você, o senhor... Diferenças devidas somente à seleção dos textos, ao tipo de personagens caracterizadas, ou preconceito (avaliação negativa) no registro daquilo que, afinal de contas, já devia estar em uso na sociedade, mesmo da capital federal? Para este trabalho, levantei ainda os dados de duas obras de Catulo da Paixão Cearense (Meu Sertão e Sertão em Flor), que residiu boa parte de sua vida no Rio. Pois bem, apesar de registrar algumas das variantes de vossa mercê — vancê(s), vaincê(s), vassuncê, vasmincê e mecê, não utiliza nem o pronome você! Diferença regional?

\section{REFERÊNCIAS}

ALMEIDA, Palmira Morais Rocha de. Dicionário de autores no Brasil colonial. Lisboa: Edições Colibri, 2003.

ARINOS, Afonso Obra completa. [Org. sob a dir. de Afrânio Coutinho]. Rio de Janeiro: MEC/INL, 1969.

BALLY, Charles . 1965 [1925] Langue écrite et langue parlé. In: BALLY, Charles. 1965 [1925]. Le langage et la vie. 3. édition augmentée. Genève: Droz. p. 68-72.

BANDEIRA, Manuel. Tradução pra caçanje precedida de comentários. O mês modernista, 07.01.1926. In: BATISTA, Marta Rossetti et al. 1972. Brasil, 1. ${ }^{\circ}$ tempo modernista - 1917-1919, 1926 p. 273-274

BATISTA, Marta Rossetti et al Brasil: 1. ${ }^{\circ}$ tempo modernista - 1917/29. Documentação. São Paulo: IEB/USP. In: PINTO, Edith Pimentel. O português do Brasil, 1981. p. 208-209. 
CEARENSE, Catullo da Paixão. Sertão em flor. 4. ed. Rio de Janeiro: Livraria Castilho, $1928[1920]^{34}$

Meu sertão. 12. ed. Rio de Janeiro: Bedeschi, 1946 [1918].

CHAVES, Elaine A implementação do pronome Você: a contribuição das pistas gráficas. Dissertação de Mestrado. Belo Horizonte: Faculdade de Letras, UFMG, 2006.

CINTRA, Luís F. Lindley. Sobre formas de tratamento na língua portuguesa. Lisboa: Livros Horizonte, 1972.

DENÓFRIO, Darcy F.; SILVA, Vera Maria T. (Orgs.) Antologia do conto goiano, I: dos anos dez aos sessenta. 2. ed. Goiânia: Cegraf/UFG, 1993.

Dicionário Houaiss da língua portuguesa. Rio de Janeiro: Objetiva, 2001.

Estudos Filológicos. Volume dedicado à memória de Antenor Nascentes. Org. por Raimundo Barbadinho Neto. Rio de Janeiro: Academia Brasileira de Letras, 2003.

Feira dos Anexins. [Obra posthuma de D. Francisco Manuel de Melo. Agora dada à luz pela primeira vez. Edição revista e dirigida por Innocencio Francisco da Silva.] Lisboa: Livraria de A. M. Pereira — Editor, 1875.

MATOS, Gregório de. Obra poética. 2 vols. 2. ed. [Ed. de James Amado. prep. e not. de Emanuel Araújo]. Rio de Janeiro: Record, 1990.

MELO, D. Francisco Manuel de. Cartas familiares. [Pref. e notas de Maria da Conceição Morais Sarmento]. Lisboa: INCM, 1981 [1664].

Fidalgo Aprendiz. Introd. e notas de António Correia de A. Oliveira. Lisboa: Livraria Clássica Editora, 1943 [1665].

MENON, Odete P. S. A história de você. In: GUEDES, Marymarcia; BERLINCK, Rosane A.; MURAKAWA, Clotilde A. A. (Orgs.). Teoria e análise lingüísticas: novas trilhas. Araraquara: LEFCL/ São Paulo: Cult. Acadêmica, 2006. p. 99-160

NASCENTES, Antenor. O linguajar carioca. 2. ed. Rio de Janeiro: Organização Simões, 1953 [1922].

Fórmulas de tratamento no Brasil nos séculos XIX e XX. Revista portuguesa de filologia, Coimbra, v. III, tomos I e II. pp. 52-68. In: Estudos Filológicos. 2003. [1949-1950]. p. 417-433.

. O tratamento de "você" no Brasil. Separata de Homenaje a Rodolfo Lenz, Santiago do Chile, 1955, pp. 307-14. In: Estudos Filológicos, 2003. [1955]. p. 434445.

${ }^{34}$ Sempre que foi possível localizar, indiquei entre colchetes a data da primeira edição da obra. 
Obras métricas de D. Francisco Manuel de Mello. En Leon de Francia: Horacio Boessat y George Remeus. 03 tomos, 1665.

O conto do Rio de Janeiro. Seleção e notas de R. Magalhães Júnior. Rio de Janeiro: Civilização Brasileira, 1959.

OLIVEIRA, António Correia de A. 1943. Introdução. In: MELO, D. Francisco Manuel de. Fidalgo aprendiz. Introd. e notas de António Correia de A. Oliveira. Lisboa: Livraria Clássica Editora. 1943 [1665]. p. 01-34.

PADILHA, Viriato. Os roceiros. Rio de Janeiro: Livraria do Povo, 1899.

PEREIRA, Nuno Marques. Compêndio narrativo do Peregrino da América. 6. ed. completada com a $2 .^{\mathrm{a}}$ parte, até agora inédita, acompanhada de notas e estudos de Varnhagen, Leite de Vasconcelos, Afrânio Peixoto, Rodolfo Garcia e Pedro Calmon, em dois volumes. Vol. II. Rio de Janeiro: Academia Brasileira, 1939.

PERES, Fernando da Rocha; LA REGINA, Silvia. Um códice setecentista inédito de Gregório de Mattos. Salvador: Edufba, 2000.

PINTO, Edith Pimentel. O português do Brasil: textos críticos e teóricos. 2. 1920/1945

- Fontes para a teoria e a história. São Paulo: EDUSP, 1981.

PIRES, Cornélio. Patacoadas. Itu: Ottoni, 2002 [1926].

Poesias de Paulino C. Vasconcellos, Abbade de Jazente. Nova edição. Tomo I. Lisboa: na Typographia Rollandiana, 1837.

RAMOS, Jânia. O uso das formas você, ocê e cê no dialeto mineiro. In: HORA, Dermeval. (Org). Diversidade lingüística no Brasil. João Pessoa: Idéia, 1997. p. 4360.

RIBEIRO, Júlio. A carne. 20. ed. Rio de Janeiro: Francisco Alves, 1946 [1888].

SARMENTO. Maria da Conceição. Prefácio, II parte. In: MELO, D. Francisco Manuel de. Cartas familiares. [Pref. e notas de Maria da Conceição Morais Sarmento]. Lisboa: INCM, 1981 [1664]. p. 31-44.

SILVA NETO, Serafim da. O português do Brasil. In: Miscelânea filológica. Niterói, Gráfica Dias Vasconcelos, 1940, pp. 3-8. In: PINTO, Edith Pimentel. O português do Brasil, 1981. p. 366-370.

Introdução ao estudo da língua portuguesa no Brasil. 4. ed. Rio de Janeiro: Presença, 1977 [1950].

História da língua portuguesa. 3. ed. Rio de Janeiro: Presença, 1979 [1957]. 
SILVEIRA, Agenor. 1962 [1920]. Prefácio da primeira edição. In: SILVEIRA, Valdomiro. Os caboclos (contos). 3. ed. Introd. crít. de Dirce Cortes Riedel. Rio de Janeiro: Civilização Brasileira, 1962 [1920]. p. IX-XI.

SILVEIRA, Valdomiro. Os caboclos (contos). 3. ed. Introd. crít. de Dirce Cortes Riedel. Rio de Janeiro: Civilização Brasileira, 1962 [1920].

Leréias (histórias contadas por eles mesmos). (contos). 2. ed. Notas biogr. por Júnia Silveira Gonçalves. Folclore do BR na obra de Valdomiro Silveira por Rossini Tavares de Lima. Rio de Janeiro: Civilização Brasileira/ INL-MEC, 1975 [1945].

WEINREICH, U.; LABOV, W.; HERZOG, M. Empirical foundations for a theory of language change. In: LEHMANN, W.; MALKIEL, Y. (Eds.). Directions for historical linguistics. Austin, Texas: University of Texas Press, 1968. p. 97-195. 